Canadian Journal of Family and Youth, 13(3), 2021, pp. 385-390

ISSN 1718-9748@ University of Alberta

http://ejournals,library,ualberta.ca/index/php/cjfy

\title{
The Various Aspects and its Effects on the Mental Health of Immigrants and Refugees
}

\author{
Sameera Tariq, MacEwan University
}

\section{Introduction}

Immigration is a broad term that underlines the travel of one person from their origin country to another country and settles as a permanent resident for a particular reason, such as schooling, improved living conditions and/or better opportunities. Children contribute greatly towards immigration as they are the main purpose that serves to populate the nation and helps offset declining fertility rates. The policies of immigrating have changed drastically over the years which has allowed many people to migrate to Canada as a family with many having young children. In comparison, the term refugee is mainly defined as "one that flees". Refugees are defined as people who seek aid and shelter in another country and are unable to return to their home country for fear of persecution based on their race, religion, nationality, political opinion or simply being a member of a certain group (Albanese, 2020, pp. 147-48).

Even though both immigrants and refugees are viewed as newcomers to a new country, the difference between the two underlies the fact that immigrants choose to move to a new country, whereas, refugees are forced to flee their home country due to circumstances (Refugees and Immigrants: A Glossary, 2010). Immigration is not a random or easy process. The requirements of arrival inside a host country are based on a balance of compassion, economic self-interest and international commitments. Most migrant families are healthy, well-educated, and occupationally skilled since a health examination is mandatory for admission into Canada. Accordingly, migrants from Asia, Middle Eastern, Africa and Latin America make up 75\% of the population of newcomers to Canada. Refugees can be divided into two groups: those who make their way to Canada and then qualify for refugee status under the UN Convention definition and those who are selected because of high-risk situations abroad (Beiser et al., 1995, p. 67).

Children play a considerable role in the immigration process. During pre-migration and post-migration, children encounter many complications that they must overcome to fit into the new values, norms and culture of the host country. The many contingencies and outcomes of migration lead to stress for many immigrants and refugee children, affecting their mental health. 


\section{Literature Review}

Immigrant and refugees can have a hard time adapting to a new country. One of the ways in which moving to a new country affects immigrant and refugee children is by having an impact on their mental health. From the year 1986 to 1991, Canada had 819,000 immigrants and refugees come and live here. Out of these 819,000 migrants, 157,000 (roughly 19\%) were children under the age of 12 (Beiser et al., 1995, p. 67). The path of migration is filled with risks and stress before and after arrival to a new country. A model was constructed to explain the contingencies and outcomes that migration has on a child's health, well-being, psychopathology, academic success, and self-esteem. According to the diagram, it has shown that pre and post migration stressors directly affect well-being. On the contrary, personal and social resources can affect the well-being of immigrant children directly but, when it acts as a buffer for adversity, it indirectly affects wellbeing (Beiser et al., 1995, p. 68).

Research and results have suggested that immigrants and refugees children are at a greater risk for substance abuse, delinquency and depression, post-traumatic stress disorder (PTSD) and psychopathology than native-born individuals (Beiser et al., 1995, p. 67). In research from Rutter et al. (1974), he had concluded that immigrant children in London had displayed higher rates of psychiatric disorders then their native-born peers. On the contrary, a Ontario child health study had shown that the occurrence of psychiatric disorders in immigrant and native-born children portrayed no differences (Beiser et al., 1995, p. 69).

Migration to the host country can affect the health of immigrant children as they are exposed to new nutrients, diets and pathogens (Beiser et al., 1995, p. 68). According to the results of various studies, Mexican-American procrastinate in children immunization, Latin women tend to resist having children, non-native black women are less likely to make prenatal and postnatal visits to their origin countries, and overall, immigrants tend to use fewer health services that are provided foreign-born. Another study which was conducted in Quebec studied the effects of migration on perinatal health. The results of this study had found that assimilated women tended to have under weight infants due to the influences of migration by adopting bad habits during their pregnancy, such as smoking or an inappropriate diet (Beiser et al., 1995, p. 68).

Refugees endure enormous stress as they are exposed to traumatic experiences such as experiencing violence, living in a country at war, death of a loved one, murder, parental imprisonment, separation from family or communities, and being put in refugee camps. Refugees also face a great amount of discrimination as they are viewed negatively nationwide (Walker \& Zuberi, 2020, p. 397) by being portrayed as fake or push-ins by the media (Beiser et al., 1995, p. 68). A 2017 survey of Canada had displayed that $40 \%$ of Canadians were accepting of Syrian refugees settling in the host country, $36 \%$ were indifferent to the idea and $24 \%$ of citizens wanted to outright ban the settlement of Syrian refugees in Canada (Walker \& Zuberi, 2020, p. 401). According to Walker and Zuberi (2020, p. 398) school-age Syrian refugees who displayed psychological traumatic symptoms upon arrival are at a higher risk for mental health and have difficulty in academic achievement but, the display and experience of discrimination can further affect the existing symptoms.

Specifically, immigrant and refugee children who have been separated from family members early on in their resettlement are at an increased risk for mental health. Studies have 
shown that refugee children who have witnessed violence in their home country and have experienced dangerous and risky journeys to another country are at a higher risk of having posttraumatic stress disorder. Evidently this has been proven by studies that have been conducted on survivor children of the Holocaust which has shown that long-term symptoms of PTSD have been persistent (Beiser et al., 1995, p. 68). Another study that took place in the Turkish refugee camp examined 311 Syrian children and found that $79 \%$ had witnessed a family member dying, $30 \%$ had been shot at, kicked, or physically injured, and $45 \%$ of children refugees had experienced PTSD (Walker \& Zuberi, 2020, p. 399).

Many conditions can be of risk to the mental health of a migrant child: poverty, family instability, death of a loved one, separation from one or both parents, parental psychological distress, unemployment, attacks on their self-esteem, inter-racial conflict, or even intergenerational conflicts. Studies have shown that $31 \%$ of immigrant and refugee children live in unstable, poor, or even dangerous areas during their early years of settlement in the host country. According to other research, $36.4 \%$ of immigrant children lived in poor families compared to the $13.3 \%$ nativeborn children. Research suggests that even though poverty had a significant effect on emotional and behavioural problems, it had very little variation on sociodemographic factors (Beiser et al., 2002, p. 222).

Psychopathology, which is the study of mental disorders, is the result of exposure to affliction and the interaction between exposure and vulnerability. This helps explain the results of many studies that have focused on immigrant children. A comparative study elaborated on the difference between migrant children living in functional families versus immigrant children living with depressed mothers or in unstable families. The results of this study had proven that immigrant children living in such uncertain conditions were less likely to deal with racism at school well and less likely to do good in school putting them at a more, likely rate to become juvenile delinquents (Beiser et al., 1995, p. 69).

Some personal resources such as a secure identity and language abilities of the host country can have an effect on the outcomes of migrant children's well-being. However, children have the ability to learn a new language without an accent until the beginning of puberty or sometimes even after but do not attain true fluency in the language at this point (Beiser et al., 1995, p. 69).

On the other hand, research has shown that many immigrant and refugee children view education as an important aspiration due to cultural traditions, parental ambitions and the anxiety of being a minority status. Several immigrant parents tend to maintain an ethnic resilience while living in the host country. In other words, these parents do not submit to the culture of the host country due to pressure and maintain their own ethnic pride and cultural identity (Beiser et al., 1995 , p. 69). Many families tend to adapt to biculturalism which allows them validation and reaffirmation of identity by both cultures (Pumariega et al., 2005, p. 587). Research has shown that the children of these parents perform better in schools than children whose parents have submitted and assimilated fully to the culture of the host country. Other studies have proven that children who use their native language as well as English adjust and perform better in school than children who only use English (Beiser et al., 1995, p. 70).

However, the separation of parental and host country values may be hard leading to an effect on the mental health of children. This is due to the fact that some immigrant parents who come from contemporary countries may find the values and practices of Canada hard to understand 
(Beiser et al., 1995, p. 69). Even though the mainstream culture may be at time hard to maintain for some immigrant groups, those who assimilate fully to the dominant culture experience a sense of loss which threatens their personal identity (Pumariega et al., 2005, p. 585). However, when values of both the family culture and the host culture conflict with one another, many families experience an increase in intergenerational cultural dissonance, family conflicts and even violence (Pottie et al., 2015, p. 1563).

Intergenerational conflicts can also arise among families as children learn the culture and language of the host country faster than their parents. This puts children at a disadvantage as some parents are unable to help their children in their education and homework and most children have to act as translators for their parents. The result of this produces a role reversal in families which upsets the balance of normality of communication and authority (Beiser et al., 1995, p. 69).

Another dynamic that affects the migration of children is their age upon arrival in the host country. Studies have concluded that children who arrive as youngsters or children who are born in the host country to migrant parents are more likely to embrace the majority cultural values and may even experience more intergenerational conflicts or problems than people who arrive in Canada as young adults. The similarity of ethnicity in a community can also contribute to the selfesteem and psychological resilience of migrant children. A study compared the academic achievements and depression of unaccompanied refugees in ethical and nonethical foster homes which indicated that Southeast Asian refugee children placed in similar ethical homes obtained higher GPAs and developed less depression than children who were placed in Caucasian family homes (Beiser et al., 1995, p. 70).

The success of immigrants does not depend entirely on the characteristics of their communities and their outcomes but also on the context of the host country (Washbrook et al., 2012) as each host country differs in their approaches towards nation-building techniques and in the management of their diverse populations (Vang \& Chang, 2018, p. 603). The most popular countries for migrants to settle in are Australia, Canada, the United Kingdom, and the United States due to their long history of receiving immigrant, having similar national identities and ethnic communities and allowing citizens to be open and flexible (Washbrook et al., 2012). These countries also display many differences as the United States racial community has been framed around a black/white divide. Therefore, immigrants arriving in the United States immediately start to distance themselves socially and spatially from the African-Americans due to the racial boundaries. On the other hand, Canada does not strongly frame its ideologies on a racial divide as it is a greatly multicultural country where cultural diversity is not only tolerated but welcomed to a great extent (Vang \& Chang, 2018, p. 604).

Although this does not suggest that settled immigrants never experience discrimination. Vang \& Chang conveyed that 52\% of immigrants had reported that they experience some form of discrimination every day. Correspondingly, immigrants had indicated that the top three main causes of perceived discrimination were based on race, other factors (e.g., physical disability, sexual orientation, weight, appearance, income, etc.), and gender (Vang \& Chang, 2018, p. 615).

Evidently, there have been various studies that have examined the effects that discrimination, racism, and bullying have on learning, well-being, health and assimilation of immigrant and refugee children (Walker \& Zuberi, 2020, p. 403). According to many studies, first generation adolescent immigrants who had migrated from non-English speaking countries had 
reported having experienced more bullying and violence at school than native-born adolescents. There was also evidence of a positive correlation between children feeling safe in their learning environments and academic success. Reportedly, first generation Latin American had reported feeling more unsafe at schools than second, third or later Latino generations. The results also stated that first generation Latino Americans had reported less suicide attempts then the second generation, with the third generation displaying the highest rate of suicide (Pottie et al., 2015, p. 1562).

Another study used a qualitative approach to measure the experiences of violence in schools and communities of immigrant children by interviewing 42 first-generation immigrant children. The study had found that many children had experienced some sort of physical aggression or verbal abuse in their school environment (Brabant et al., 2015, p. 248).

\section{Conclusion}

In conclusion, migration is a complicated process for many immigrants and refugees. Immigrants and refugees are similar as they both leave their home countries to settle into a host country. They differ in that immigrants come to the host country by will whereas, refugees are forced to flee due to circumstances. Many families will leave their home country for a better and suitable life for themselves and their children. While living in the host country, children of many families can be subject to risks, traumas, discrimination, depression, and even PTSD. Many of the migration outcomes can directly or indirectly affect children's well-being, mental health, and academic success. Migrant children also often feel conflicted between their family culture or the

host country's culture, leading to intergenerational cultural dissonance and family conflicts between parents and the child. 


\section{References}

Albanese, P. (2020). Children in Canada today. In Children in Canada today (Third ed., pp. 135151). Don Mills, Ontario: Oxford University Press.

Beiser, M., Dion, R., Gotowiec, A., Hyman, I., \& Vu, N. (1995). Immigrant and Refugee Children in Canada. The Canadian Journal of Psychiatry, 40(2), 67-72.

Beiser, M., Hou, F., Hyman, I., \& Tousignant, M. (2002). Poverty, Family Process, and the Mental Health of Immigrant Children in Canada. American Journal of Public Health, 92(2), 220-227. https://doi.org/10.2105/ajph.92.2.220

Brabant, L. H., Lapierre, S., Damant, D., Dubé-Quenum, M., Lessard, G., \& Fournier, C. (2015). Immigrant Children: Their Experience of Violence at School and Community in Host Country. Children \& Society, 30(3), 241-251. https://doi.org/10.1111/chso.12131

Merriam-Webster. (n.d.). Immigration. In Merriam-Webster.com dictionary. Retrieved March 28, 2021, from https://www.merriam-webster.com/dictionary/immigration

Pottie, K., Dahal, G., Georgiades, K., Premji, K., \& Hassan, G. (2014). Do First Generation Immigrant Adolescents Face Higher Rates of Bullying, Violence and Suicidal Behaviours Than Do Third Generation and Native Born? Journal of Immigrant and Minority Health, 17(5), 15571566. https://doi.org/10.1007/s10903-014-0108-6

Pumariega, A. J., Rothe, E., \& Pumariega, J. B. (2005). Mental Health of Immigrants and Refugees. Community Mental Health Journal, 41(5), 581-597.

Refugees and Immigrants: A glossary. (2010, September). Canadian Council for Refugees. https://ccrweb.ca/en/glossary

Vang, Z. M., \& Chang, Y. (2018). Immigrants' Experiences of Everyday Discrimination in Canada: Unpacking the Contributions of Assimilation, Race, and Early

Socialization. International Migration Review, 53(2), 602-631.

Walker, J., Zuberi, D (2020). School-Aged Syrian Refugees Resettling in Canada: Mitigating the Effect of Pre-migration Trauma and Post-migration Discrimination on Academic Achievement and Psychological Well-Being. Int. Migration \& Integration 21, 397-411.

Washbrook, E., Waldfogel, J., Bradbury, B., Corak, M., \& Ghanghro, A. A. (2012). The Development of Young Children of Immigrants in Australia, Canada, the United Kingdom, and the United States. Child Development, 83(5), 1591-1607. https://doi.org/10.1111/j.1467$\underline{\text { 8624.2012.01796.x }}$ 